\title{
Phenology
}

\section{The Study of Recurring Natural Phenomena}

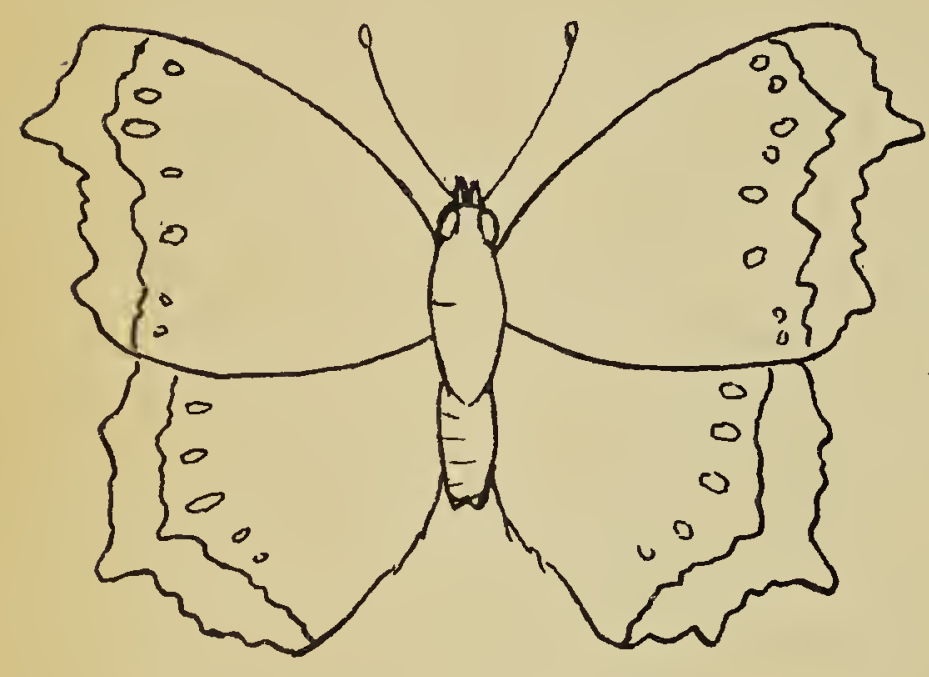

Sketch by Joyce Dew

MOURNING CLOAK BUTTERFLY

Recently a group of four Regina naturalists, three of them employed by the Museum, noticed an interesting coincidence: each had observed the first appearance of the Mourning Cloak Butterfly on April 6 this year. The observations took place in four different localities: Riverhurst, Joyce Dew; Regina, R. Nero; King's Park, F. Brazier and Mortlach, F. Lahrman. In the ensuing discussion, someone commented on the amazing fact that year after year one species of bird too will appear in the same locality on practically the same date. Further discussion led to our attention being drawn, by Dr. Nero, to a scientific study of "first appearances": a phenological record for Sauk and Dane Counties, Wisconsin, 1935-1945. (1947. Ecological Monographs, 17:81-122) by Aldo Leopold and Sara Elizabeth Jones. An article in the Canadian Field-Naturalist for April-May, 1943, called Phenology, the Most Natural of Sciences by R. Glendenning deals with the same subject. Ideas and, in fact, whole paragraphs have been "lifted" from these studies for this article.

Phenology is described as "the study of recurring natural phenomena" and this science is alive among farmers, gardeners, Indians and nature lovers whose work or interests are outdoors. Among contemporary phenologists we find also botanists, foresters, game managers, ornitholo: gists, range managers and zoologists Phenology, in short, is a "horizonta science" which transects all ordinar biological professions. Whoever see the land as a whole is likely to have an interest in it. Phenology is mor ancient that the "vertical" categorie which it transects; its first paper published about 974 B.C., cuts acros three sciences then not yet born meteorology, botany and ornithology

For, lo, the winter is past

The rain is over and gone;

The flowers appear on the earth

The time of the singing of birds i come

And the voice of the turtle is hearc in our land.

(Solomon 2:12

Records of seasonal incidents ir both plant and animal life are kep by those interested in this science Plant records usually consist of date of first leafing, flowering or appear ance of autumnal color. Native plant are most frequently used. The time of arrival and departure of migran birds provide good records of season. al aetivity and the first songs o resident species are also useful. In sects are used to a lesser extent; the earliest flight of the honey bee is : staple record and, as noted above, the butterflies may be fairly constant ir their appearance.

The recording of seasonal occur. rences has been criticized by som as an interesting hobby but of little scientific value; however, phenologi. cal studies when properly organized using data from hundreds of obser. vers-sifted, tabulated and averagec - may yield some striking facts rela. tive to climate, wild life, and cycle of growth. In England, studies hav shown that cycles of growth havi occurred with an average length o 12.1 years. For a discussion of : possible cycle in the numbers 0 Snowy Owls see Blue Jay for Decem. ber, 1957, page 155. In the Wisconsir study, which is very detailed anc deserves careful study, an exampl of a practical use for phenologica data is given. A game manager learn: from scientific data that the most fre. quent date of first egg-laying ir 
pheasants is May 6. What else is going on at that time? Records show spring grain well up, the Franklin Ground Squirrel has emerged, blue grass will head out in eight days, Sugar Maple, Chokecherry and other plants are in first bloom. In a year when the season is advanced, the same game manager may start looking for eggs when the other phenomena mentioned were observed.

Part of the terrain for which data was gathered in Winconsin was prairie, so the table showing the first blooming of prairie plants is of interest to us. The following dates are given for familiar plants: Pasque Flower (April 10); Hoary Puccoon (May 2); Shooting Star (May 16); Lilac-flowered Beard-tongue (June 14). it is interesting to compare these dates with the following supplied by Mr. Lloyd Carmichael, Regina: Pasque Flower (April 8) ; Hoary Puccoon (May 6); Shooting Star (June 4); Lilac-flowered Beard-tongue
(June 18). A chart prepared by Arch. C. Budd giving the flowering sequence of spring plants may be found in the March 1957 Blue Jay.

For those who are keeping records of first appearances, R. Glendenning has some useful suggestions. Plant records kept should be of cultivated plants that are successfully grown in your area, or of native plants growing in a location where they are unlikely to be destroyed, such as on wild land or roadsides. It is important that records be kept for the same location each year. Frogs croaking should be recorded from the same swamp, and birds from the same farm or similar area. Records kept in this way from year to year have significant comparative value. When they have been kept for many years, these records are also interesting to other people keeping similar records. A comparison of such long-term records would make a worthwhile study for the Blue Jay.

\section{Mammal Notes}

\section{Skunk Attacked by Badger}

by Joyce Gunn, Spirit Lake, Sask.

At sunset on January 7 Mother and were walking towards home along a well-packed road when we saw just ahead of us a skunk hurrying south in our direction. We decided discretion was the better part of valour and stepped off into the snow to give the skunk the right of way! It paused only momentarily to look at us then continued southward at a skunk gallop.

As we stepped back on to the road we saw the reason for the half-grown skunk's haste. It was being chased along the road by a badger. The bader stopped, however, when he saw us and turned back north. We followed him for about 100 yards before he turned off into the bush, bleeding profusely from one of his front paws. He wasn't much larger than the skunk. Watching the scene from a poplar near the road was a great horned owl that flew just as we saw the badger coming.

A few yards north of where the badger turned off we came to a spot that reeked of skunk, and then about fifty yards further on we came to the the battle area. Skunk and badger must have gone at it tooth and nail, for the hard-packed snow was bloodstained and discoloured and there were claw marks around. Closer to home we saw where the skunk had come out of the bush, and farther on, the badger. Apparently the badger had been wounded before tackling the skunk as there were faint blood stains on his trail before he got to the road.

Two days later I heard that the skunk was killed by a dog a half mile south of where we had met it and only ten minutes later-so he was really making time! People also remarked on the fact that the skunk seemed to be wounded. No doubt he was exhausted after his run, to say nothing of his fight with the badger. 